\title{
GERAKAN KEAGAMAAN DAN IDENTITAS KULTURAL MASJID JENDRAL SUDIRMAN YOGYAKARTA
}

\author{
Fejrian Yazdajird Iwanebel \\ Universitas Islam Negeri (UIN) Sunan Ampel, Surabaya \\ Jl. Ahmad Yani No.117, Jemur Wonosari, Kec. Wonocolo, Kota Surabaya, \\ Jawa Timur 60237 \\ Email: iwanebel@uinsby.ac.id
}

Abstract: The article aims at explaining the root and the form of religious based cultural movement initiated by Jendral Sudirman Mosque (MJS) Yogyakarta. The conundrum departs from the common assumption that mosque is usually regarded as the sacred place, not as profane as cultural performance. Since 2011, the MJS has carried out various cultural activism that is unique, paradox and distinct from the common mosques which activites are generally centered on religious piety. It is in this case that this paper discusses MJS from two aspects: the history of the MJS and its cultural strategy. In its history, the MJS underwent three phases of movement. At first, the mosque was subjugated by the militant Islamic movement which aims at establishing an Islamic state. The movement, then, shifted into an educational movement of the children. And later, it changed totally into religious cultural movement. At this regard, the cultural movement carried out by the MJS reflects an effort in shifting their old identity, while at the same time they are involved in a discursive approach to respond the contemporary challenge of Islamism.

Keywords: Jendral Sudirman Mosque, Cultural Movement, Islamism.

Abstrak: Artikel ini membahas tentang akar sejarah dan praksis gerakan keagamaan berbasis kebudayaan yang ada di Masjid Jendral Sudirman (MJS) Yogyakarta. Paradoks gerakan ini berangkat dari asumsi umum bahwa masjid pada umumnya dianggap sebagai tempat suci (sacred) yang berfungsi untuk mentransendensikan diri, bukan untuk pagelaran budaya yang bersifat profan. Dalam realitasnya, sejak tahun 2011-an MJS telah melakukan berbagai aktivisme kultural yang unik, paradox dan berbeda dari mayoritas masjid lainnya yang umumnya hanya menjadikan masjid sebagai lokus kesalehan. Dalam latar inilah artikel membahas MJS dari 
dua aspek: historisitas MJS dan strategi kebudayaannya. Dalam sejarahnya, MJS mengalami tiga fase perubahan gerakan: mulai dari gerakan Islam garis keras, gerakan pendidikan anak, dan gerakan kultural keagamaan. Gerakan kultural yang diterapkan oleh MJS pada dasarnya mencerminkan usaha untuk menggeser identitas lama yang melekat pada sejarah masa lalunya, sekaligus memainkan peran diskursif dalam merespon tantangan Islamisme yang semakin menguat di masyarakat.

Kata kunci: Masjid Jendral Sudirman, Gerakan Kebudayaan, Islamisme.

\section{A. Pendahuluan}

Masjid menjadi salah satu titik sentral pergerakan dakwah Islam. Ia adalah ruang publik bagi kaum Muslim untuk berkumpul dan berdiskusi tentang berbagai persoalan agama, sosial, politik dan kebudayaan. Dalam sejarahnya, masjid memiliki berbagai fungsi yang dinamis. Nabi Muhammad menggunakan ruang ini sebagai tempat untuk berdakwah dan menjelaskan hakikat agama Islam kepada umatnya. Selain itu, Nabi juga memfungsikan ruang ini sebagai tempat untuk menerima tamu dan ut usan dari semenanjung Arabia. Pada masa Dinasti Umayyah, masjid mulai menjadi ruang publik yang kental dengan aroma politik. Ia digunakan oleh penguasa untuk membangun opini publik dengan mengeksploit asi para khotib sebagai corong legitimasi otoritas keagamaan penguasa (Pedersen: 1953, 217; Athamina: 1992, 55). Sedangkan pada zaman Abbasiah, isu-isu politik mulai terpinggirkan dari masjid dan masuk ke dalam ruang-ruang privat. Masjid pada masa ini lebih berfungsi sebagai ruang pengembangan keilmuan (Pedersen: 1991, 644-677).

Fungsi masjid menjadi semakin inklusif seiring dengan dinamika sosial yang ada. Tidak sedikit masjid yang kemudian menjalankan fungsi-fungsi sosial keagamaan seperti bidang pendidikan dan ekonomi. Pada tahun 2013, Jusuf Kalla, ketua Dewan Masjid Indonesia saat itu, telah mencanangkan program perekonomian berbasis masjid dengan menggandeng perbankan syariah. Selain itu, dia juga bertekad untuk membangun Pendidikan PAUD di setiap masjid. Meski dalam realitanya tidak semua masjid mengimplementasikan program yang telah dicanangkan, perkembangan kedua bidang tersebut bisa ditemukan di banyak masjid yang tersebar di seluruh Indonesia.

Berbeda dari latar gerakan sosial berbasis masjid yang telah digariskan di atas, Masjid Jendral Sudirman Yogyakarta (selanjutnya disingkat MJS) 
justru memilih jalur aktivitas yang distingtif. Dengan tidak menegasikan ciri khas utama masjid sebagai ruang publik keagamaan, MJS lebih tertarik untuk menapaki jalur kebudayaan sebagai latar aktivismenya. Masjid ini cukup konsisten dalam mengembangkan strategi kult ural sejak tahun 2011. Ia layak untuk dikatakan sebagai penggerak budaya, Jawa khususnya, karena beberapa kegiatan yang dilakukan sangat identik dengan ekspresi kebudayaan, yang di antaranya adalah ceramah budaya, "ngaji" wayangan, tembang Jawa, mocopat, serat-serat sunan dan suluk Jawa, serta kajian filsafat. Bahkan ketika bertepatan dengan momentum hari besar Islam, MJS juga turut berpartisipasi dalam meramaikan aspirasi kebudayaan masyarakat dengan beberapa agenda kultural, seperti zikir "Joged Sholawat Mataram" atau biasa disebut dengan tarian wirid keliling (wirling) pada saat pengajian syawalan, mubeng beteng pada bulan suro, dan arak-arakan at au pawai kebudayaan dengan menggandeng kaum kadang.

Artikel ini mengulas secara historis tentang negosiasi identitas dan praksis kebudayaan yang dilakukan oleh para aktivis MJS hingga memunculkan inisiatif gerakan kultural berbasis masjid. Gerakan kultural MJS faktanya tidak berada dalam ruang a-historis. Setidaknya, terdapat isu sosial yang cukup pelik dalam kontinuitas sejarahnya di mana pada tahun 1980-an, masjid ini dikenal sebagai tempat yang kental dengan isu gerakan radikal dan merupakan kepanjangan dari jaringan Islamisme Solo yang berpusat di Ngruki, di bawah kepemimpinan Abu Bakr Ba' asyir dan Hasan Basri (Solahuddin: 2011, 146). MJS pada tahun-tahun tersebut kerap menjadi incaran pemerintah karena menjadi basis gerakan Islam radikal yang cenderung berorientasi pada penegakan negara Islam. Dalam konteks inilah, gerakan kebudayaan MJS bisa dilihat sebagai sebuah gerakan responsif terhadap tantangan Islamisme yang melekat pada sejarah masa lalunya.

\section{B. Sejarah Awal Berdirinya Masjid Jendral Sudirman}

Pada mulanya, Masjid Jenderal Sudirman bukanlah masjid yang besar. Masjid ini semula hanya sebuah musala kecil yang digunakan untuk aktivitas rutin keagamaan, seperti salat berjamaah. Awalnya, keberadaan musala ini merupakan "cabang" dari Masjid Syuhada yang terletak di Jl. I Dewa Nyoman Oka, Kotabaru, Gondokusuman, Kota Yogyakarta. Dikatakan cabang karena dari Masjid Syuhada inilah cikal bakal pendirian Masjid Jenderal Sudirman bermula. 
Pendirian MJS berawal dari sebuah ikatan persahabatan, di mana beberapa pendiri MJS awal adalah mereka yang aktif dalam kegiatan di Masjid Syuhada. Bahkan, sebagian dari mereka memegang jabatan sebagai anggota takmir Masjid Syuhada. Hingga kini, Yayasan Masjid Syuhada masih menjadi masjid yang berkembang pesat, di mana di dalamnya terdapat berbagai lembaga pendidikan, baik formal, mulai dari TK, SD, SMP IT, dan Sekolah Tinggi Agama Islam Masjid Syuhada, maupun non-formal seperti masjlis zikir dan majlis taklim.

Aktor utama pendirian Masjid Jenderal Sudirman ada tiga, yaitu Halim Tuwasikal, Zubair Qohari dan Adi Winata. Ketiganya bertempat tinggal di kompleks Kolombo, kompleks perumahan elit yang dulu merupakan milik pemerintah, yang digunakan oleh presiden Soekarno sebagai tempat singgah untuk para tamu-tamu negara. Halim Tuwasikal adalah seorang wartawan media massa Kedaulatan Rakyat. Adapun Zubair Qohari adalah seorang pengusaha batik sukses. Sedangkan Adi Winata, tidak banyak informasi yang didapatkan mengenai kehidupannya. Namun yang perlu digarisbawahi, mereka bertiga merupakan orang yang berafiliasi dengan organisasi masyarakat Muhammadiyah, di mana basis gerakan ormas ini berpusat di Yogyakarta. Masjid Syuhada sendiri pada masa lalu merupakan masjid yang erat kaitannya dengan aktivit as ke-Muhammadiyah-an.

Misi pendirian masjid ini pada dasarnya tidaklah monolitik. Ia tidak hanya didasari oleh dasar-dasar teologis. Jika dilihat dalam lanskap historis dan geografis, pendirian MJS pada dasarnya cenderung lebih bersifat politis. Dari kaca mata sejarah, gerakan dakwah keislaman yang muncul pada era ini lekat dengan misi anti-kristenisasi. Asumsi ini diperkuat dengan latar geografis akan keberadaan dua institusi keagamaan non-Islam yang berdiri di sekitar kawasan tersebut yang sangat mungkin menjadi alasan terselubung (soft reasoning) bagi para inisiator untuk melakukan gerakan keagamaan demi membendung laju kristenisasi. Dua instansi yang berada di dekat MJS adalah Universitas Sanata Dharma dan SMA Kolese De Brito. Kampus Sanata Dharma sendiri merupakan kampus tua yang di dalamnya terdapat bangunan gereja besar yang sering digunakan sebagai pusat gerakan doktrinasi agama Katholik. Kedua institusi yang berafiliasi ke Katholik tersebut mempunyai jaringan yang kuat ke dalam dan ke luar instansi. Di luar instansi, mereka memiliki jejaring hingga ke Roma. Misalnya, proses perubahan nama yang terjadi pada tanggal 9 Juni 1953, perubahan nama tersebut diinisiasi oleh 
Fejrian Yazdajird Iwanebel: Gerakan Keagamaan dan Identitas Kultural Masjid Jendral Sudirman Yogyakarta.... (hal. 173-194)

Pembesar Serikat Jesus di Roma, nama SMA Santo Johanes De Britto kemudian diubah menjadi SMA Kolese De Britto. Latar historis dan posisi geografis MJS ini nampaknya memiliki paralelitas dengan masjid Syuhada yang merupakan cikal bakal MJS. Tidak jauh dari lokasi masjid Syuhada, 350 $\mathrm{m}$ ke selatan, terdapat gereja besar yaitu Gereja Katolik Santo Antonius Padua. Di sebelah timur masjid Syuhada, berjarak 400 m, juga terdapat SMA Stella Duce.

Dalam sebuah cerita yang disampaikan oleh aktivis MJS, pembangunan MJS awalnya direncanakan untuk pembangunan Islamic Center (Pusat dakwah Keislaman), di mana harapannya Islamic Center ini memiliki gedung yang megah sebagai simbol eksistensi umat Islam sekaligus meramu berbagai kegiatan untuk menyemarakkan aktivitas keagamaan Islam, mulai dari ritual hingga sosial keislaman. Namun, rencana tersebut tidak terealisasikan, dan akhirnya terbent uklah MJS sebagai institusi keislaman yang sengaja dihadirkan di tengah masyarakat plural yang ada di kawasan "trikomplek": Kolombo, Mrican dan Demangan. Dengan demikian, secara historis pendirian MJS memiliki misi counter identity (identitas tandingan) terhadap eksistensi keagamaan lain yang ada di sekitarnya.

\section{MJS dan Awal Gerakan Sosial Keagamaan}

Fase awal gerakan yang dilakukan oleh para aktivis (baca: pengurus) MJS adalah gerakan keagamaan. MJS pada fase ini tidak banyak mengakomodir gerakan-gerakan politis kecuali hanya bertindak sebagai penyelenggara ritual keagamaan an sich. Masjid, pada fase ini, hanya digunakan sebagai tempat beribadah, karena posisi MJS saat itu hanyalah sebuah musala atau langgar yang hanya dipergunakan untuk melakukan salat lima waktu secara berjama'ah. Hingga kemudian pada fase berikutnya, di mana penggalangan dana mulai dilakukan secara massif dan mendapatkan sumbangan dana yang cukup melimpah, MJS mulai bergeliat ke arah gerakan keagamaan yang lebih meluas. MJS sebagai institusi keagamaan yang mampu menyandang dana yang besar, pada gilirannya mampu membeli sepetak tanah yang cukup luas, di mana kini tanah tersebut difungsikan sebagai bangunan untuk masjid, kantor masjid, SMA Kolombo, dan SD Muhammadiyah komplek Kolombo.

Sejarah awal berdirinya masjid-masjid di era 60 -an tidak bisa dilepaskan dari pengaruh DDII (Dewan Dakwah Islamiyah Indonesia) yang didirikan oleh M. Natsir (1908-1993) dan para mantan pemimpin Masyumi. Organisasi ini 
didirikan pada tahun 1967 dengan tujuan merealisasikan cita-cita mereka yang sempat pupus dalam memperjuangkan negara berlandaskan syariat. Gerakan yang mereka populerkan dalam organisasi ini adalah dakwah. Namun perlu ditegaskan bahwa gerakan dakwah tersebut bukanlah gerakan kultural, melainkan gerakan dakwah puritan yang ditumpangi oleh ideologi Islamis yang menginginkan tercapainya cita-cita negara Islam dengan menerapkan Piagam Jakarta (Hasan: 2008, 46).

Pada tahun 70-an, MJS mengalami perubahan orientasi gerakan keagamaan. Perubahan orientasi tersebut terletak pada keinginan beberapa oknum yang aktif di dalam MJS untuk melakukan perubahan haluan pergerakan. Sifat lokalitas yang semula berupaya sebagai counter identity, kemudian berubah menjadi lebih puritan dan bersifat revolusioner. Beberapa pihak yang terindikasi aktif di dalamnya memiliki semangat untuk merubah haluan pancasila menjadi Negara Islam Indonesia (NII).

Tercat at dalam sebuah rekaman sejarah, pada awal Mei 1987, Yusuf Latief dan kawan-kawan seperti Hasan Bauw dan Mulyono, membentuk struktur gerakan Islamis di masjid ini. Gerakan Islamis ini merupakan kepanjangan jaringan Islamis Solo yang berpusat di Ngruki, di bawah kepemimpinan Abu Bakr Ba'asyir dan Hasan Basri (Solahuddin: 2011, 146). Di masjid ini, perekrutan anggota dilakukan secara massif, dengan melakukan berbagai kegiatan yang beraliran ideologi kanan. Tent unya gerakan tersebut sangat tidak mentolerir bentuk-bentuk keagamaan yang bersifat kult ural, karena hal itu dianggap sebagai sesuatu yang melenceng dari agama (baca: bid'ah). MJS pada tahun-tahun tersebut kerap menjadi incaran pemerintah karena sering dijadikan basis gerakan Islam radikal yang cenderung berorientasi menegakkan syariat Islam maupun negara Islam, dan itu tentu menjadi ancaman tersendiri bagi sebuah negara.

Jika dilihat dari akar kesejarahan, gerakan yang berafiliasi ke haluan kanan at au radikal tersebut mempunyai motivasi yang kuat untuk tidak hanya menegakkan syariat semata, namun gerakan ini bisa dilihat dari akar perpolitikan nasional, di mana presiden Soeharto ketika itu menerapkan Pancasila sebagai asas tunggal. Sehingga gerakan dan organisasi apapun yang tidak berhaluan dengan Pancasila dinilai sebagai ancaman terhadap Negara. Imbas dari penerapan pancasila sebagai asas tunggal ini menjadikan banyak orang berbondong-bondong beralih ke ideologi yang tidak beroposisi dengan 
pancasila. Muhammad Natsir yang semula merupakan aktivis Muslim dan politisi yang berafiliasi kepada Masyumi pun beralih kepada gerakan yang secara lahiriah tidak bertent angan dengan asas tunggal pancasila. Namun, Natsir kemudian menerapkan strategi gerakan ideologisasi islamisme melalui lembaga-lembaga pendidikan.

Dalam situasi yang terdesak inilah militansi mereka justru semakin meningkat. Alasan teologis untuk menerapkan syariat sudah tidak lagi menjadi alasan yang paling dominan dalam pemikiran mereka. Bagi mereka, merampas kekuasaan pemerintah saat itu adalah satu-sat unya cara untuk membebaskan diri dari cengkeraman pemerintah yang sangat brutal dalam membatasi gerakan-gerakan keagamaan.

Misi pemberontakan ini juga diakui oleh salah satu alumni MJS, Toha, yang mengatakan bahwa pada tahun-tahun 80 -an proses ideologisasi keislaman radikal banyak dilakukan di MJS. Hanya saja, tidak semua takmir mengikuti gerakan dan aliran tersebut. Hanya beberapa yang aktif dalam gerakan islamisme it u. Meski hanya beberapa oknum yang terlibat, proses ideologisasi tersebut berjalan secara massif. Hampir semua takmir pada dasarnya mengalami proses ideologisasi model keislaman radikal yang digawangi oleh para aktivis seperti Irfan S. Awwas. Meski Irfan S. Awwas sendiri bukanlah orang yang bermukim di MJS, resonansinya cukup menggema dalam melakukan doktrinasi terhadap para takmir masjid MJS. Bahkan, Toha sendiri mengakui bahwa dia mendapat pesan dari Irfan untuk menyembunyikan seluruh dokumennya ketika polisi datang melakukan operasi ke tempat tersebut.

Proses ideologisasi ini melibatkan seluruh takmir masjid MJS yang saat itu dikelola oleh sembilan orang yang bermukim di asrama MJS. Asrama ini dikhususkan bagi mereka yang mau untuk mengurus dan aktif menggiatkan kegiatan-kegiat an masjid MJS. Mayoritas para penghuni asrama MJS ini adalah para mahasiswa yang sedang menempuh pendidikan di kampuskampus Yogyakarta. Menurut Toha, angka sembilan ini pada dasarnya mengacu pada jumlah walisongo yang juga berjumlah sembilan. Sembilan orang inilah yang mendapatkan hak privasi untuk tinggal di asrama sampai mereka menyelesaikan studinya di Yogyakarta. Rata-rata, mahasiswa tingkat sarjanalah yang menghuni asrama ini. Sistem rekruitmen yang dilakukan juga tidak menggunakan sistem yang ketat. Perekrutan hanya dilakukan dengan 
menggunakan modal jejaring sosial berbasis persahabatan antar teman. Sistem inipun berjalan dari waktu ke waktu hingga saat ini. Oleh karenanya, Toha mengatakan bahwa sejak dulu motivasi para penghuni asrama MJS bukanlah motivasi ideologis, seperti ingin menegakkan syariat atau menjadi aktivis muslim yang ketat, namun justru motivasi ekonomilah yang menggerakkan mereka untuk tinggal di asrama MJS. Bagi mahasiswa yang berasal dari daerah dengan uang saku yang tidak banyak, tentu tinggal di asrama MJS yang tidak dipungut pembiayaan rumah, dan bahkan mendapat insentif tambahan dari pengelolaan masjid, adalah hal yang sangat menggiurkan. Maka, dari sistem perekrutan pun sebenarnya tidak menampakkan bahwa secara institusi, MJS ini mempunyai orientasi aktivitas keislaman yang ketat seperti ditampilkan oleh kelompok-kelompok islamisme yang radikal. Hanya beberapa oknum, yang menurut pengakuan Toha berjumlah tiga orang, yang mempunyai misi islamisme yang kuat serta gencar dalam melakukan diseminasi model keislaman radikal.

Ketiga oknum itulah yang justru mempunyai pengaruh kuat dalam menandaskan islamisme ke dalam MJS. Dalam sepekan sekali mereka mengadakan kajian rutin yang berisikan ideologisasi dan doktrinasi tentang bagaimana menjadi muslim yang kaffah (sempurna). Proses doktrinasi ini juga melibatkan para penghuni asrama. Mereka menggunakan perndekatan persuasif kepada para penghuni asrama. Para penghuni lainnya yang tidak datang ke dalam kajian tersebut akan merasa sungkan, karena para ideolog tersebut menggunakan doktrin agama yang nampaknya cukup ampuh untuk menjerat mereka ke dalam lingkaran kajiannya. Dalam kajian tersebut, proses ideologisasi itu meliputi kewajiban untuk menghafal QS. al-Fath: 29, yang menjadi dalil untuk melegitimasi sikap keras terhadap orang-orang kafir. Sikap inilah yang kerap dimunculkan oleh kelompok-kelompok islamisme yang mengarah pada gerakan radikal. Pada fase ini, MJS sudah tidak lagi bertindak sebagai counter identity, namun lebih dari itu, mereka bergerak secara agresif untuk bersikap keras terhadap orang-orang kafir. Mereka yang kafir dalam ayat di atas sering dialamatkan kepada mereka yang beragama non-Muslim, terlebih mereka yang menganut agama Nasrani, di mana saat itu cukup gencar dalam isu kristenisasi. Maka, sikap keras ini menurut hemat mereka adalah sikap yang tepat untuk dihadapkan kepada kelompok non-Muslim yang ingin merebut massa kaum Muslim.

Aktivitas doktrinasi juga tidak hanya menggunakan ayat-ayat maupun 
hadis nabi yang menyuruh untuk melakukan aksi jihadis. Mereka juga menggunakan lagu-lagu nasyid yang bertemakan jihad unt uk membangun semangat heroisme keislaman dalam sanubari mereka. Lagu-lagu nasyid yang di antaranya menyerukan untuk terus melakukan jihad dan memerangi orang kafir terus digelorakan dan dinyanyikan dalam setiap pertemuan. Bahkan, lant unan khas kelompok islamisme dengan jeritan "Allahu akbar" selalu muncul dalam setiap kali resonansi gertakan dari pimpinan mereka ketika selesai berbicara dengan menggebu-gebu untuk berjihad.

Target utama mereka dalam melakukan aktivitas keislaman adalah untuk menumbangkan rezim yang menurut mereka telah banyak melakukan represi terhadap gerakan-gerakan keislaman. Selain itu, isu pembantaian Muslim juga menjadi topik yang cukup sensitif yang selalu digelorakan oleh para aktivis untuk merebut hati kaum Muslim agar mau untuk melakukan aksi perlawanan dengan atas nama jihad.

Masa ini berakhir ketika gerakan-gerakan separatis mereka, yang dilakukan oleh oknum tertentu, terendus oleh pemerintah. Dan MJS mendapatkan getahnya karena masjid ini seringkali digunakan sebagai basecamp dalam melakukan persebaran aktivisme keislaman di Yogyakarta. Irfan S. Awwas yang saat it u sangat gencar dengan gerakan islamisme pada akhirnya ditangkap dan dimasukkan ke dalam penjara. Beberapa polisi dan TNI juga seringkali keluar masuk ke MJS untuk memastikan sterilisasi MJS dari sarang islamisme yang sempat bernaung di bawah bendera masjid ini. Sejak saat itu, aktivisme keislaman yang ada di MJS mulai redup dan tidak ada lagi tandatanda untuk hidup kembali.

\section{MJS dan Gerakan Pemulihan Identitas}

Pada tahun 1985-an, aktivitas islamisme di MJS mulai meredup seiring dengan gencarnya pemerintah melakukan operasi penangkapan para aktivis Muslim yang berusaha untuk menumbangkan rezim pemerintahan Soeharto. Peristiwa ini menjadi titik awal terjadinya perubahan orientasi keislaman yang ada di MJS yang semula kental dengan nuansa islamis, menjadi sebuah gerakan keislaman yang mempunyai orientasi pada bidang edukatif. Sebelum sampai pada orientasi pendidikan, MJS mengalami masa vakum yang cukup lama, sekitar lima tahun. Dalam jeda waktu ini, label islamisme dan gerakan radikal masih melekat di MJS, sehingga para takmir pun tidak banyak melakukan aktivitas yang mencurigakan. Kegiatan-kegiatan yang dilakukan 
pada masa-masa vakum ini tidak banyak, hanya kegiatan rutin yang dilakukan sehari-hari seperti melakukan salat lima waktu secara berjama'ah dan menyelenggarakan salat Jum'at. Aktivitas pengajian hampir tidak mendapat ruang karena kekhawatiran para takmir akan memunculkan kembali represi pemerintah yang masih selalu mengawasi situasi di MJS. Masyarakat sekitar juga tidak banyak bersuara, karena mereka juga khawatir ketika berurusan dengan pemerintah yang saat itu memang memiliki kekuasaan penuh dalam mengendalikan aparatur sipil dan tentara-tentara kenegaraan. Bahkan dalam pengakuan Toha, masyarakat juga menjadi lebih takut dan antipati paska penggerebekan di MJS. Mereka melarang anak-anak untuk datang ke masjid.

Hingga pada awal tahun 1990-an, para takmir MJS mulai menemukan format baru dalam meramaikan kembali aktivitas MJS yang sempat terpuruk. Berawal dari kegiatan "ngaji" (baca tulis Alquran) yang dilakukan pada sore hari, kegiatan ngaji anak-anak ini semakin ramai dan menjadi titik simpul identitas baru yang ada di MJS. Nuansa baru tercipta dari kegiatan ini. Masjid yang sebelumnya sepi, mulai bergeliat kembali.

Format baru yang digiatkan adalah format pendidikan anak-anak yang dikenal dengan TPA(Taman Pendidikan Anak-anak). Pengajian anak-anak ini di MJS diberi nama PAS (Pengajian Anak-anak Soedirman). Kegiatan ini berjalan cukup lama, mulai tahun 1990-an hingga 2005. Ini merupakan masa keemasan di mana TPA saat itu memiliki magnet yang cukup kuat untuk menarik kembali minat masyarakat untuk bergabung dan meramaikan MJS. Bahkan dalam beberapa kesempatan, MJS menjadi role modelpengembangan TPA berbasis masjid, dan sempat menjadi TPA terbaik di Yogyakarta. Beberapa TPA dari berbagai daerah, seperti Bandung, juga pernah menyelenggarakan study tour ke Yogyakarta dalam rangka untuk belajar tentang sistem pembelajaran TPA yang ada di MJS.

Realitas ini pada dasarnya menjelaskan bahwa orientasi gerakan keagamaan yang terjadi pada tahun 1990-an hingga awal 2000-an lebih banyak didominasi oleh orientasi pendidikan. MJS pada fase ini hendak menjadikan masjid sebagai pusat dakwah melalui anak-anak. Dan ini merupakan salah satu strategi untuk menutup lubang hitam yang pernah hinggap dalam sejarah perkembangan masjid MJS.

\section{E. Gerakan Kebudayaan MJS}

Pada fase selanjutnya, strategi keagamaan MJS lebih banyak mengarah 
pada gerakan kebudayaan. Adalah Yasser Arafat yang dalam pembacaan penulis merupakan aktor utama (human agency) di balik gerakan kebudayaan ini. Dia adalah salah satu takmir atau pengurus MJS yang mempunyai latarbelakang pendidikan agama di UIN Sunan Kalijaga dan Antropologi di Universitas Gajah Mada. Dia merupakan orang Aceh yang mempunyai darah keturunan Jawa. Yaser sendiri mempunyai kecenderungan dalam kajian kebudayaan Jawa. Pertama kali datang ke MJS pada tahun 2000-an, Yaser saat itu menjadi mahasiswa UGM dengan mengambil kajian kebudayaan tentang qira'ah dan tilawah (cara baca Alquran dengan suara merdu). Pat ut dicatat bahwa pada tahun 2000-an, dia menjadi orang pertama yang berani menyuarakan langgam Jawa untuk membaca Alquran dalam salat jama'ah. Praktik pembacaan inilah yang pada satu dekade berikutnya, tepatnya pada $15 \mathrm{Mei}$ 2015, bergulir menjadi sebuah diskursus nasional. Hal itu terjadi ketika Yaser Arafat mengumandangkan bacaan tilawah ayat Alquran dengan langgam Jawa dalam acara peringat an Isra Miraj di Istana Negara. Langgam Jawa yang biasa dikumandangkan oleh Yaser yang semula hanya bersifat lokal, kemudian pengaruhnya meluas hingga tingkat nasional bahkan internasional. Langgam jawa pada titik ini menjadi sebuah diskursus yang tidak henti-hentinya menjadi bahan diskusi hangat di kalangan Muslim praktisi maupun akademisi. Diskursus mengenai langgam Jawa pun mulai bergeliat secara nasional, bahkan dijadikan oleh kelompok konservatif, seperti Rizieq Shihab, sebagai pendulum untuk mendeligitimasi kepemimpinan presiden (hidayatullah.com, 19 Mei 2015). Di sisi lain, Quraish Shihab, seorang akademisi bidang Alquran, juga memberi tanggapan tentang tidak adanya ketentuan baku dalam pembacaan Alquran dengan langgam tertentu, karena yang terpenting adalah terpenuhinya tajwid dalam membaca Alquran (republika.co.id, 23 Mei 2015).

Pada tahun 2011, ketika Yasser kembali ke Jogja unt uk menempuh studi lanjut, dia kembali bertempat tinggal di MJS. Pada masa-masa ini, aktivitas kebudayaan yang ada di MJS berjalan semakin meriah. Berbagai kegiatan yang bernuansa kebudayaan, spiritualitas dan intelektualitas cukup banyak mewarnai kegiatan-kegiatan yang ada di MJS. Bahkan, MJS tidak lagi menjadi kegiatan pendidikan anak-anak, namun justru menjadi idola bagi mahasiswa. MJS pada periode ini banyak menjadi rujukan dan mayoritas pendatang kajian-kajiannya berasal dari kalangan mahasiswa. Kegiatan-kegiatan seperti sinau (belajar) tembang mocopat, "ngaji" wayangan, tembang Jawa, seratserat sunan dan suluk Jawa, serta filsafat (Jawa) menjadi agenda rutin Masjid 
dalam mengembangkan kerangka kebudayaan Jawa. Selain itu, agenda kultural, seperti zikir "Joged Sholawat Mataram" atau biasa disebut dengan tarian wirid keliling (wirling) pada saat pengajian syawalan, mubeng beteng pada bulan suro, dan arak-arakan atau pawai kebudayaan dengan menggandeng kelompok kadang, juga menjadi rutinit as kultural yang sengaja dihidupkan oleh takmir MJS dalam rangka "nguri-ngur"' (menghidupkan kembali) kebudayaan Jawa.

Katalistor utama gerakan kebudayaan ini adalah untuk membalikkan fakta bahwa MJS pada dasarnya bukanlah masjid yang beraliran radikal. Menurut pengakuan Yasser, ketika MJS dihuni oleh kelompok radikal, masyarakat enggan untuk mendekat ke masjid, dan ketika nuansa kebudayaan digalakkan, masjid mulai semarak. Yaser juga menjelaskan bahwa di antara jama' ah masjid ada yang menuturkan bahwa "masjid ini semakin ramai dan sering "dikunjungi" oleh para leluhur".

Setelah puluhan tahun lamanya gerakan radikal tidak berkembang di MJS, pihak pengurus masjid tidak mendapatkan kritikan bahkan ancaman dari kelompok tersebut, mereka justru mendapat dukungan penuh dari masyarakat untuk terus mengobjektivikasi kebudayaan sebagai latar gerakan masjid. Gerakan kebudayaan ini lambat laun melekat sebagai identitas baru masjid MJS. Dengan arah kebudayaan tersebut MJS menjadi salah satu "masjid kebudayaan" yang berpusar di tengah derasnya arus globalisasi dan radikalisasi kelompok kanan yang umumnya menggunakan masjid sebagai basis gerakan.

\section{F. Strategi Kebudayaan Masjid Jendral Sudirman}

Gelombang Islamisme yang cukup besar, utamanya setelah runtuhnya orde baru, yang terjadi di berbagai daerah membuat beberapa kalangan bergerak untuk menyikapinya dengan berbagai strategi. Banyak di antara kaum "kultural" yang tidak menampakkan gerakannya melalui aksi frontal, namun dengan menggunakan jalur kebudayan. Masjid Jendral Sudirman merupakan salah satu institusi keagamaan yang menggunakan jalur kebudayaan dalam merespon bentuk-bentuk Islamisme yang kian masif. Respon yang ditunjukan oleh MJS, menunjukkan bahwa masjid ini tidak bersikap frontal terhadap fenomena gerakan Islamisme. MJS justru seakan mengisi ruang kosong yang tidak banyak dijadikan sebagai titik pijak dalam merespon gerakan Islamisme. Ruang kosong tersebut adalah kebudayaan. Bagi mereka, 
menghidupkan kebudayaan sama halnya dengan menetralisir gerakan islamisme. Pasalnya, ideologi dan gerakan islamisme seringkali berbenturan dengan tradisi kebudayaan lokal. Islamisme seringkali merujuk pada tradisi Arab yang dianggap sebagai absolute culture (budaya suci) yang diturunkan dari tradisi kenabian.

Jika dilihat secara lebih mendalam, diskursus antar kelompok Islam ini umumnya lebih berada pada titik cara pandang, di mana kelompok-kelompok kanan, umumnya lebih menitikberatkan pada aspek tekstualitas Alquran dan hadis. Sebaliknya, kelompok-kelompok moderat justru lebih mengedepankan perspektif kontekstual dalam membaca teks-teks Alquran maupun hadis. Sehingga, pemahaman terhadap teks, misalnya tentang perbudakan, potong tangan, dan jilbab merupakan produk hukum yang bersifat temporal, dan umat Islam saat ini tidak harus melaksanakan produk hukum tersebut secara ketat (Saeed: 2006).

Berikut ini penulis akan memaparkan beberapa strategi kebudayaan yang dilakukan oleh para aktivis Masjid Jendral Sudirman:

\section{KaJian FILSAFAT DAN KEBUdAyAan JAWA}

Masjid selalu identik dengan kegiatan ritual dan sosial keagamaan. Tidak sedikit, bahkan mayoritas masjid hanya digunakan sebagai ritual peribadatan dan transfer keilmuan melalui mimbar dan podium khutbah maupun ceramah. Sangat sedikit para takmir masjid yang memikirkan kegiatan sosial keagamaannya sebagai penopang intelektual. Masjid Jendral Sudirman merupakan salah satu pengecualian. Di dalamnya terdapat banyak kajian yang mengarah pada diskursus keilmuan. Di antaranya adalah kajian filsafat yang diselenggarakan setiap malam kamis. Kajian ini sudah berjalan cukup lama, dengan mendatangkan pembicara Dr. Fahruddin Faiz, dosen UIN Sunan Kalijaga Yogyakarta.

Kajian ini diisi dengan berbagai teori-teori filsafat mulai dari klasik sampai kontemporer. Wahana keilmuan yang kental dengan suasana akademik ini dihadirkan oleh MJS untuk kalangan mahasiswa. Sangat jarang masyarakat sekitar yang ikut andil dalam kegiat an ini. Hal tersebut dapat dipahami karena materi tersebut tidak mudah untuk diserap kalangan masyarakat. Materi kajian yang disampaikan juga tidak hanya berasal dari kalangan pemikir Barat. Para filosof Muslim dalam salah satu serial kajiannya juga dibahas secara sistematis. Kajian ini bisa dikatakan sebagai kajian primadona dalam MJS. Pasalnya, 
pembicara yang berasal dari UIN Sunan Kalijaga tersebut mempunyai kepiawaian dalam membahasakan filsafat ke dalam bahasa yang sederhana dan dengan logika yang mudah dipahami. Dibawah ini merupakan pengakuan salah satu peserta yang rutin mengikuti kajian filsafat di MJS, Halimah Garnasih,

"Tapi apa yang saya dapatkan selama mengaji sungguh tidak sebanding dibandingkan dengan perjuangan yang cuma apalah-apalah itu. Bagaimana penyampaian Pak Faiz yang ringan dan sederhana, analogi-analogi yang sangat keseharian dan dekat dengan kita mampu membuat pikir dan nurani, mata akal dan mata batin saya menekur. Mengeja pelan-pelan. Menghayati dalam-dalam. Hingga.... saya merasa tahu apa yang semestinya saya lakukan. Bagaimana semestinya saya berjalan di atas kehidupan. sungguh bekal laku hidup...." (Garnasih: 2016)

Dari kutipan di atas, kita dapat melihat bagaimana implikasi psikologi dan intelektual yang berpengaruh terhadap para peserta kajian filsafat di MJS. Peserta nampak lebih mempunyai cara pandang yang mendalam tentang arti kehidupan mereka. Dalam beberapa hal, kajian ini jelas membawa para peserta untuk tidak terkotak dalam cara berpikir pendek, apalagi berpikir secara tekstualis.

Menurut Yaser Arafat, takmir penggagas kajian filsafat, bahwa tujuan diadakannya ngaji filsafat dan kegiatan-kegiatan lain oleh pengelola Masjid Jendral Sudirman (MJS), tak lain adalah untuk menghidupkan dan memakmurkan fungsi Masjid itu sendiri, sebagai alat pemersatu umat Islam. Jadi, fungsi Masjid ini, tidak hanya untuk arena ritual seperti shalat, dzikir dan i'tikaf saja, akan tetapi juga kegiatan-kegiatan keagamaan yang lain, seperti diskusi, tempat ngumpul-ngumpul, belajar bareng, dan lain sebagainya. Semua acara itu bisa diikuti oleh siapapun, dari kalangan manapun, tanpa dipungut biaya sepeserpun. Oleh karenanya, para pegiat kajian ini tidak hanya berasal dari kalangan Muslim. Beberapa pelajar non-Muslim yang berasal dari Universitas Sanata Dharma juga seringkali ikut berpartisipasi dalam kegiatan ini.

\section{Seni Budaya Berbasis Spiritualitas}

Strategi lain yang juga diakselerasikan oleh para pengelola MJS adalah dengan menyelenggarakan kegiatan-kegiat an kebudayaan Jawa. Cukup banyak kegiatan bernuansa kebudayaan Jawa yang dihadirkan dalam masjid 
ini. Di antaranya, Joged Mataraman. Kegiatan ini merupakan salah satu ritual sufi yang menggunakan kesenian tari sebagai wasilah (medium) untuk mendekatkan diri kepada Tuhan. Model tarian sufistik ini mirip dengan fenomena whirling dance (tarian memutar) yang diinisiasi oleh Jalaluddin al-Rumi dan kemudian banyak ditiru oleh para Darwis. Secara historis, tarian memutar ini berasal dari sebuah kerinduan ( 'ish $q$ ) seorang Jalaluddin al-Rumi yang ditinggal oleh gurunya Syamsuddin Tabrizi. Dia kemudian mengekspresikan dirinya untuk mendekatkan diri kepada Tuhan melalui tarian.

Joged Mataraman ini merupakan salah satu tradisi peninggalan kerajaan Mataram. Tarian ini merupakan tarian spiritual yang menggabungkan antara agama dan kebudayaan. Tarian ini, meski mengusung spiritualit as seperti tari memutar, namun gerakan yang diperagakan tidaklah seperti tari memutar. Joged Mataraman lebih mengedepankan aspek keluwesan dalam gerak, kesatuan alam pikiran, dan kewaspadaan terhadap diri sembari menyatukan ruhani ke dimensi ketuhanan. Pelaku tari jogged Mataraman yang kini masih eksis adalah Raden Kushariyono Arief Wibowo, at au sering dipanggil Wibbie Mahardikka. Dia merupakan salah seorang keturunan dari kerajaan Yogyakarta. Ayahnya bernama KRT Purbowijoyo, dan kakeknya yang bernama KRT Purbaningrat merupakan orang yang dulunya aktif dalam melakoni tarian Mataraman ini dengan nuansa keraton Yogyakarta (Suryadilaga: 2015, 540).

Penyelenggaraan Tari Joged Mataraman oleh para pengelola MJS yang berkolaborasi dengan kelompok Shalawat Mataram memunculkan "paradoks" baru dalam gerakan keagamaan berbasis masjid. Masjid yang umumnya hanya digunakan sebagai wahana doktrinasi dan ideologisasi keislaman, justru menjadi ruang publik yang menawarkan kesenian. Namun, nilai spiritualitas yang ada dalam tari jogged Mataraman menjadikan kesenian ini bukan sekedar pagelaran seni, namun juga meneguhkan nilai-nilai spiritualitas yang dekat dengan nilai keagamaan. Dari hal ini dapat digarisbawahi bahwa MJS berusaha untuk meneguhkan suatu identitas, di mana masjid tidak hanya digunakan sebagai produksi kesalehan dan berorientasi keakhiratan, namun juga digunakan sebagai agen reproduksi kebudayaan.

Kegiatan kebudayaan kedua adalah nasyid dan burdahan. Kegiatan kebudayaan ini pada dasarnya tidaklah baru, karena telah jamak dilakukan oleh masyarakat Muslim baik di tempat peribadhan maupun di rumah-rumah 
warga. Penyelenggaraan burdahan ini umumnya dilakukan ketika warga mempunyai hajat tertentu. Dan dalam aspek lain, tradisi burdahan ini mampu menjadi modal untuk mempertahankan kohesi sosial.

Model aktivitas kebudayaan lain yang diselenggarakan oleh MJS adalah ngaji sufisme Ibn 'Arabi. Kitab yang dikaji adalah Turjuman al-Aswaq karya Ibn 'Arabi. Kitab ini merupakan kitab "babon" dan sangat popular di kalangan Sufis. Mereka yang ingin mendalami sufisme, maka kitab ini adalah rujukan utama dalam refleksi sufistik. Tasawuf Ibn 'Arabi tidak banyak dikaji di kalangan pesantren, karena tingkat an sufisme Ibn 'Arabî dipandang terlalu ekstrim dan mengarah pada panteisme. Sebagai alternatif, nama Imam alGhazali nampaknya lebih popular dalam kajian sufisme daripada ibn 'Arabi. Dalam konteks ini, menghadirkan kajian tasawuf Ibn 'Arabi di tengah-tengah masyarakat plural merupakan sebuah strategi yang menarik. Pasalnya, Ibn 'Arabi dipandang sebagai sufi yang meletakkan dasar-dasar pluralitas keagamaan. Di samping itu, tasawuf Ibn 'Arabi lebih banyak bersifat dialektis yang menyerap terminologi filsafat sebagai kerangka pemikirannya.

Selain kajian tasawuf Ibn 'Arabi, MJS juga kajian tasawuf Jalal al-Din al-Rumi, dengan kitab Ruba 'iyyat. Kitab ini lebih banyak mendiskusikan tentang kehidupan yang berlandaskan pada falsafah cinta $(h u b b)$. Kajian lain yang juga diselenggarakan oleh MJS terkait dengan upaya menghidupkan budaya Jawa adalah dengan mengadakan ngaji serat Jawa. Kajian ini cukup unik, karena tidak mengkaji kitab-kitab klasik yang berasal dari Timur Tengah. Dalam konteks ini, MJS nampak ingin menghidupakan episteme kebudayaan dengan menyelenggarakan kajian serat-serat Jawa. Epistemologi budaya Jawa inilah yang menurutnya mampu menawarkan spiritualitas baru di tengah gegap gempita modernitas dan pendeknya sumbu literasi masyarakat saat ini.

\section{Strategi Literasi berbasis Masjid}

Strategi ini cukup unik dan jarang dilakukan oleh takmir-takmir masjid lainnya. Dengan memanfaatkan potensi dan semangat kaum muda yang mayoritas berasal dari kalangan mahasiswa, takmir MJS berusaha menghidupkan literasi di tengah spiritualitas dan intelektualitas yang mereka selenggarakan. Dalam hal ini, Hakim, salah satu takmir MJS, mengatakan bahwa literasi ini berfungsi untuk memfasilitasi dan mendokumentasikan kegiatan-kegiatan dan pemikiran para jama' ah atau peserta kajian-kajian yang 
diselenggarakan oleh MJS. Dari sekian kajian yang diselenggarakan, kelas filsafat memang menjadi kelas favorit. Mungkin hingga saat ini, 150 topik kajian di kelas filsafat sudah pernah berlangsung. Itu artinya, kegiatan tatap muka kelas filsafat ini sudah berjalan lama, sejak tahun 2013. Salah satu buku paling akhir yang diterbitkan oleh MJS berjudul Suluh Kebahagiaan, merupakan hasil karya para peserta yang ikut dalam kelas kajian filsafat. Kelas yang diasuh oleh Fahruddin Faiz ini nampaknya mempunyai pengaruh yang signfikan dalam membangun tradisi intelektual dan literasi dalam MJS.

Buku tersebut menjelaskan tentang aspek kebahagiaan dalam kehidupan manusia. Dalam buku ini, perspektif filsafat menjadi cara pandang yang dominan. Empat penulis yang telah menyumbangkan gagasannya, yaitu Agus Yuliono, Mukhlisin, Saifullah Muhammad, dan Ainia Prihatini, merupakan peserta yang aktif mengikuti kajian kelas filsafat. Dalam pengatar yang ditulis oleh Fahruddin Faiz sendiri, dijelaskan bahwa

"awalnya memang dari sejenis ngaji di masjid, Ngaji Filsafat, sehingga tokoh yang diangkat dan mode analisis yang digunakan terasa sekali berbau filsafat. Setidaknya, seperti itulah yang diinginkan oleh para penulisnya. Ngaji itu sendiri sudah berjalan sejak 2013 dan sudah mengkaji sekitar 130-an tema hingga saat ini. Entah kapan, pada siapa, dan di mana, tiba-tiba datang ilham, Mbok ya ngaji itu tidak hilang begitu saja setelah ngaji selesai. Maka, lahirlah (antara lain) buku ini." (Yuliono: 2016, x)

Produk tulisan yang dihasilkan oleh MJS umumnya mempunyai gaya bahasa milenial. Mereka tidak menggunakan bahasa kaku, resmi dan sesuai EYD. Barangkali ini merupakan salah satu strategi yang memang sejak awal digunakan oleh MJS dalam melakukan strategi kebudayaan. Bahasa-bahasa budaya yang cenderung fleksibel, eklektik, dan bersahaja menjadi pilihan mereka dalam mengembangkan diksi-diksi sastrawi. Kebiasaan ini sebenarnya tidak hanya muncul pada buku yang terakhir. Buku sebelumnya yang berjudul Apa Kabar Islam Kita? Esai-Esai Kaweruh Jumatan Masjid Jendral Sudirman Yogyakarta, juga menggunakan bahasa ringan yang sarat akan identitas kebudayaan Jawa. Bahasa inilah yang sepertinya mampu menyapa masyarakat, karena tidak terdistorsi dengan konsep-konsep besar yang kadang menjemukan dan membingungkan. Bahasa dikemas dalam struktur yang runt ut namun tidak kaku. Dan itulah nampaknya ciri khas yang ingin dimunculkan oleh para takmir MJS. Dalam salah satu pernyataanya, Yaser Arafat, menuliskan 
"maksud saya, tulsian-tulisan yang kami turunkan saat itu hanya tulisan berisi dalil-dalil dan konsep-konsep yang menyentuh sisi-sisi tekstual Islam saja. Meski begitu, dalil-dalil serta konseptualisasinya kami usahakan untuk tidak terlalu mengakademik, sampai-sampai harus dipahami dengan kening berkerut. Maka dari itu, kami mengupayakan agar setiap tulisan dapat menjadi bahan bacaan "unik" di tengah-tengah keterbiasaan pemahaman masyarakat." (Arafat: 2014, xii)

Berbicara tentang literasi di MJS, Yaser Arafat, penggerak budaya literasi di MJS, mengaku bahwa sebelum tahun 2007, budaya literasi ini masih kosong. Dia menjelaskan secara historis bahwa sekitar tahun 1980-an, Masjid Jendral Sudirman pernah menerbitkan bulletin Jumat bernama Al-Risalah. Para peunggawanya adalah aktivis MJS yang saat ini dikenal sebagai para penggerak gerakan Islam garis kanan atau radikal. Berhubung buletin itu cenderung melawan arus orde baru, maka ia pun tidak berumur panjang. Ia mati seiring dengan dijebloskannya beberapa punggawanya ke terali besi. Dan setelah itu, riwayat jurnalisme benar-benar tidak pernah terkabarkan (Arafat: 2014, xi).

Dari pengakuan Arafat, penggalan sejarah dalam melakukan upaya literasi di MJS mulai bergeliat kembali di penghujung tahun 2006, hingga kemudian baru terealisir pada tahun 2007. Bentuk literasi at au jurnalisme pertama yang dilakukan MJS adalah menghidupkan kembali bulletin Jumat yang dulu pernah hidup di masjid tersebut. Pada tanggal 21 September 2007, buletin Jumat itu terbit unt uk pertama kalinya, setelah sekian lama menghilang. Bulletin itu diberinama Buletin Jum'at Jendral Sudirman.

Jika dilihat dari strategi kebudayaan, MJS mempunyai modal sosial dan modal kapital yang cukup besar untuk melakukan mobilisasi massa. Modal sosial tersebut terletak dalam jejaring pelajar (mahasiswa) yang umumnya bermukim di Yogyakarta. Latar belakang mereka tersebar mulai dari kampus umum, kampus agama, kampus negeri dan kampus swasta. Mereka ini merupakan para pengembara yang umumnya menyukai kegiatan diskusi. Maka wajar, warung kopi dan tempat nongkrong di berbagai sudut kota Yogyakarta selalu dipenuhi oleh anak muda. Mereka duduk bersama sembari minum kopi dan menyulut api rokok, untuk kemudian melakukan obrolan bebas dan terkadang berujung pada diskusi serius. Dimensi sosial yang berlatar geografi kampus inilah yang menjadi modal besar bagi MJS untuk mendatangkan massa mahasiswa/i ke MJS. Bagi mereka, massa atau jama'ah 
masyarakat sudah menjadi rutinitas umum yang mudah ditangani. Namun untuk mendatangkan massa atau jama'ah mahasiswa/i, perlu menggunakan strategi sosial yang ampuh. Pada tahap inilah, strategi kebudayaan yang mereka gunakan cukup tepat untuk menarik minat para mahasiswa/i untuk mengikuti kajian-kajian di MJS.

Penyelenggaraan sekolah atau ngaji filsafat, pada dasarnya tidak bisa dilepaskan dari motif sosial ini. MJS tidak hanya ingin memfasiltiasi aspek spiritualitas an sich, karena umumnya target jama'ah yang berkiblat ke arah spirit ual lebih banyak didominasi oleh "kaum tua". Sedangkan kelompok ini tidak cukup banyak mengisi dan meramaikan MJS. Maka, target yang ingin dicapai oleh MJS adalah mendatangkan jama' ah milenial agar masjid tetap semarak dengan berbagai kegiatannya. Menurut hemat penulis, sekolah atau ngaji filsafat menjadi terobosan yang cukup besar untuk mendatangkan jama'ah mahasiswa ke MJS. Materi yang disampaikan oleh Fahruddin Faiz, dengan tidak menitikberatkan dimensi filsafat yang berat untuk dikonsumsi, namun lebih menggunakan bahasa dan logika sederhana, secara tidak langsung menjadi penanda khusus bahwa MJS merupakan masjid yang peduli dengan dunia akademik. Maka, seiring berjalannya waktu, para peserta banyak berdatangan untuk menghadiri kelas filsafat. Pada momen-momen selanjutnya, kajian yang diselenggarakan juga tidak lepas dari unsur intelektualitas. Meski dimensi spiritualitas yang terlihat, misalnya kajian tasawuf, yang dihadirkan sebagai pembicara adalah orang yang mempunyai kapabilitas intelektual yang mumpuni. Dan kitab yang dikaji pun bukanlah kitab umum yang biasa menjadi diktat di bangku perkuliahan atau pondok pesantren.

Selain itu, modal sosial ini juga didukung dengan pemanfaatan media sosial seperti facebook. Akun MJS yang hingga kini masih aktif merupakan salah satu strategi sosial untuk mensosialisasikan penyelenggaraan kegiatan di MJS. Namun demikian, satu hal unik yang ada dalam pola sosialisasi ini adalah aspek kreatifitasnya. Mereka tidak hanya menyampaikan maksud atau informasi an sich, namun dengan gaya bahasa yang cukup persuasif dan ditopang dengan bahasa-bahasa kultural yang kreatif, misalnya,

"SLUMAN SLUMUN SLAMET. Dengan rahasia alif lam mim kami mengundang diri kami sendiri untuk mengajikan diri mengangsu berkah dari kedua kanjeng sunan Jalaluddin monggo ngaji TAFSIR JALALAIN bersama Ustadz Elhamuna El-Quds. Selasa 25 Maret 2014,,,setelah maghrib,„,di Masjid Jendral Sudirman Yogyakarta,,, oh iya dilanjutkan setelah 
salat Isa' dengan Ngaji “NEMBANG MOCOPATAN,,," bersama ki Muhammad Bagus Febriyanto. Monggo mumpung jembar kalangane,,, mumpung padang rembulane,,,mumpung gratis inumane (eh keliru hihihi). Monggo-monggo-monggo,,,berkah-berkah-berkah,,”,

Bahasa kultural dan cenderung "bersahabat" inilah yang nampaknya menjadi strategi efektif dalam menjaring jama' ah untuk datang ke MJS. Dan benar saja, MJS tidak hanya dikunjungi oleh masyarakat sekitar namun juga mendapatkan simpati dari masyarakat akademis. Para mahasiswa seringkali tampak hadir dalam acara-acara kebudayaan yang digelar oleh MJS. Keberadaan mahasiswa di MJS tentu mempunyai simbol tersendiri, bahwa masjid Jendral Sudirman tidak hanya berhaluan kultural tapi juga menjalankan fungsi edukatif. Sebagaimana komposisi sosial masyarakat Yogyakarta yang cukup dominan dengan banyaknya pendatang dari berbagai daerah, khususnya para pelajar, hal ini memungkinkan MJS untuk menjalankan fungsi sosialnya sebagai agen kebudayaan dan pendidikan.

\section{Strategi Penafsiran Keagamaan Berbasiskan Kebu- DAYAAN}

Hadirnya para pembicara baik dari dalam maupun luar kota, merupakan pilihan para takmir untuk mengusung agenda kebudayaan dalam MJS. Ki Herman Sinung Janutama Yogayakarta, KH. Imron Jamil Jombang, Ki Muhammad Bagus Febriyanto Yogayakarta, Cak Kuswaidi Syafi'i dan para pembicara lainnya, merupakan deretan para tokoh yang memiliki concern dalam bidang keagamaan dan kebudayaan. Para takmir memilih mereka untuk mendemonstrasikan kebudayaan yang menjadi agenda utamanya. Dalam kajian keilmuan, unsur kebudayaan tidak pernah lepas dari diskursus yang dikembangkannya, termasuk dalam kajian tafsir. Bahkan dalam salah satu statemennya, Ki Herman Sinung Janutama pernah berkomentar bahwa membaca, mengaji dan mengkaji Alquran tidak bisa dipisahkan dari kultur Jawa. Model pembacaan ini umumnya mewarnai corak pemahaman mereka terhadap tafsir Alquran.

Salah satu landasan utama dalam menafsirkan Alquran adalah lafadz a'jami artinya bahasa non-Arab. Dia menyitir ayat-ayat yang berkenaan dengan lafadz tersebut seperti dalam QS. an-Nahl: 103, QS. Fusshilat: 44, dan QS. as-Syuara': 198 ('Abd al-Baqi: 2001, 549). Dia mengatakan bahwa meski Alquran turun dalam lisan Arab atau bahasa Arab, hal tersebut tidak 
menafikan adanya universalitas bahasa Arab yang juga bisa "dibaca" dalam kultur Jawa. Dia memberikan contoh seperti pemaknaan æÚãáæÇ ÇáÕÇálÇÊ (beramal salih, berbuat baik, saleh disini tidak harus diartikan menurut kaedah kebahasaan A rab secara letterlijk, namun dengan berusaha mencari pemahaman ala Jawa. Terhadap ayat tersebut dia menafsirkan bahwa orang yang saleh (baik), itu harus seleh (melepaskan diri atau pasrah), sumeleh (patuh kepada titah Tuhan) dan suluh (menjadi penerang). Dalam pengertian ini maka orang yang saleh adalah mereka yang bisa melepaskan diri dari nafsu egonya, mereka yang menjalankan titah Tuhan-nya dengan penuh ketulusan dan di atas itu semua mereka mampu menjadi penerang bagi orang-orang di sekitarnya.

\section{G. Simpulan}

Dari uraian di atas, dapat disimpulkan bahwa secara historis, sejarah perkembangan MJS bisa dipetakan dalam tiga masa: fase pertama yait u awal pendirian sampai tahun 80 -an, generasi ini merupakan masa kejayaan Islam kanan bertengger di masjid ini, bahkan MJS tercatat sebagai markas besar mereka dalam mengadu strategi politik maupun dakwah mereka. Aksi-aksi radikal yang sebelumnya sangat gencar disuarakan, mulai sedikit pudar pada fase kedua dan diganti dengan gerakan pendidikan Islam, yaitu awal 90-an sampai tahun 2000-an. Pada fase ketiga, mulai tahun 2005-an sampai sekarang, MJS justru berbalik arah dan cenderung melakukan upaya kritik terhadap ideologi yang sempat bersemayam di dalamnya. Ideologi yang mereka tanamkan bukan lagi gerakan radikal melainkan gerakan kultural yang menghargai nilai-nilai spiritual dan ilmu pengetahuan. Strategi kebudayaan MJS ini, menurut hemat penulis, mencerminkan adanya perubahan identitas sekaligus memainkan peran diskursif dalam merespon tantangan Islamisme yang melekat pada sejarah masa lalunya.

\section{Daftar Pustaka}

'Abd al-Baqi, Muhammad Fuad. 2001. Al-Mu'jam al-Mufahras li Alfadz alQur'an al-Karim. Kairo: Darul Hadis.

Arafat, Yaser (ed.). 2014. Apa Kabar Islam Kita? Esai-Esai Kaweruh Jumatan Masjid Jendral Sudirman Yogyakarta. Yogyakarta: MJS Press. 
IbU日' Jurnal Kajian Islam dan Budaya

Athamina, Khalil. “Al-Qasas: Its Emergence, Religious Origin and Its SocioPolitical Impact on Early Muslim Society", dalam Studia Islamica, no. 76, 1992.

Halimah Garnasih, "Pengalaman Ngaji Filsafat di Masjid Jendral Sudirman Yogyakarta, dalam http://kembangintuisi.blogspot.co.id/2016/05/ pengalam-ngaji-filsafat-di-masjid.html. Diakses pada 10 September 2018.

Hasan, Noorhaidi. 2008. Laskar Jihad; Islam Militansi dan Pencarian Identitas di Indonesia Pasca-Orde Baru, terj: Hairus Salim. Jakarta: LP3ES dan KITLV.

Pedersen, Johs. 1991. "Masdjid”, dalam C.E. Bosworth, dkk. (eds.), The Encyclopaedia of Islam, Vol. VI. Leiden: E.J. Brill. . "The Criticism of the Islamic Preacher", dalam Die Welt des Islams, Vol. 2, Issue 4, 1953.

Saeed, Abdullah. 2006. Intrepreting the Qur'an Towards A Contemporary Approach. London: Routledge.

Solahuddin. 2011. NII Sampai JI: Salafy Jihadisme di Indonesia. Jakarta: Komunitas Bambu.

Suryadilaga, Muhammad Alfatih. "Mafhûm Șalawât 'inda majmû'ât Joged Shalawat Mataram: Dirâsah fî al-Hadîth al-Ḥayy", dalam Studia Islamika: Indonesian Journal for Islamic Studies, Vol. 21, No. 3, 2014. Yuliono, Agus, dkk. 2016. Suluh Kebahagiaan. Yogyakarta: MJS Press. 